DEMOGRAPHIC RESEARCH

VOLUME 28, ARTICLE 32, PAGES 917-950

PUBLISHED 24 APRIL 2013

http://www.demographic-research.org/Volumes/Vol28/32/

DOI: $10.4054 /$ DemRes.2013.28.32

Research Article

Components and possible determinants of the decrease in Russian mortality in 2004-2010

\author{
Vladimir M. Shkolnikov
}

Evgeny M. Andreev

Martin McKee

David A. Leon

(C) 2013 Shkolnikov, Andreev, McKee \& Leon.

This open-access work is published under the terms of the Creative Commons Attribution NonCommercial License 2.0 Germany, which permits use, reproduction \& distribution in any medium for non-commercial purposes, provided the original author(s) and source are given credit.

See http:// creativecommons.org/licenses/by-nc/2.0/de/ 


\section{Table of Contents}

$\begin{array}{lll}1 & \text { Background } & 918\end{array}$

2 Methods 919

$\begin{array}{lll}2.1 & \text { Data and techniques } & 919\end{array}$

$3 \quad$ Results 920

3.1 Life expectancy at birth in Russia and comparator countries 920

3.2 Age patterns 922

3.3 Causes of death 922

3.4 Age- and cause-specific contributions to the increase in life 926

$3.5 \quad$ Russia compared with the UK 928

4 Discussion 930

4.1 Limitations 930

4.2 Cause-specific trends and international differences 931

$4.3 \quad$ Alcohol 932

$4.4 \quad$ Smoking 934

4.5 Health system performance 934

$5 \quad$ Conclusion 937

$6 \quad$ Acknowledgements 938

$\begin{array}{ll}\text { References } & 939\end{array}$

$\begin{array}{ll}\text { Appendix } & 946\end{array}$ 


\title{
Components and possible determinants of the decrease in Russian mortality in 2004-2010
}

\author{
Vladimir M. Shkolnikov ${ }^{1,2}$ \\ Evgeny M. Andreev ${ }^{2}$ \\ Martin McKee ${ }^{3}$ \\ David A. Leon ${ }^{3}$
}

\begin{abstract}
BACKGROUND

After a long decline, life expectancy in Russia substantially increased in 2004-2010; this is the longest period of health improvement that has been observed in the country since 1965. This study is the first analysis of this positive trend.
\end{abstract}

\section{OBJECTIVES}

We seek to determine the causes and age groups that account for the additional years of life gained in 2004-10 and the remaining gap between Russia and Western countries, to assess to what extent these recent trends represent a new development relative to previous mortality fluctuations, and to identify possible explanations for the improvement.

\section{METHODS}

We present an analysis of trends in life expectancy, and in age- and cause-specific mortality in Russia and selected countries in Eastern and Western Europe. We use decomposition techniques to examine the life expectancy rise in 2004-2010 and the Russia-UK life expectancy gap in 2010.

\footnotetext{
${ }^{1}$ Max Planck Institute for Demographic Research, Rostock, Germany. Corresponding author. E-mail: shkolnikov@demogr.mpg.de.

${ }^{2}$ New Economic School, Moscow, Russia.

${ }^{3}$ London School of Hygiene \& Tropical Medicine, UK.
} 


\section{RESULTS}

Like the previous mortality fluctuations that have occurred in Russia since the mid1980s, the increase in life expectancy was driven by deaths at ages 15 to 60 from alcohol-related causes. Uniquely in the recent period, there were also improvements at older ages, especially in cerebrovascular disease mortality among women. In addition, there were reductions in deaths from avoidable causes, such as from tuberculosis and diabetes. The life expectancy gap between Russia and Western countries remains large, and is mostly attributable to deaths from cardiovascular disease, alcohol-related conditions, and violence.

\section{CONCLUSIONS}

The decrease in alcohol-related mortality may be attributable to measures taken in 2006 to control the production and sale of ethanol. The lower number of cerebrovascularrelated deaths may reflect advancements in blood pressure control. The reduction in the number of deaths from tuberculosis and diabetes may be associated with a general improvement in health care. Although the decline in mortality since 2004 has been substantial, the question of whether it can be sustained remains open.

\section{Background}

Worldwide, life expectancy has increased steadily over the past six decades, with two main exceptions: the countries of sub-Saharan Africa severely afflicted by the AIDS epidemic, and the countries of the former Soviet Union (McMichael et al. 2004). However, in this latter group, it appears that there may be some grounds for optimism. Since 2004, Russia, along with most other former Soviet republics, has experienced clear and relatively steep increases in life expectancy. This is the longest period of improvement seen in Russia since the mid-1960s. What is unclear, however, is whether these trends are simply the latest phase in a continuing cycle of increases and decreases that have characterized mortality in Russia over the past three decades, or whether there are new features that mark a break from the past.

In the mid-1980s, following two decades of stagnation, life expectancy in Russia improved rapidly. This coincided with the implementation of a wide-ranging campaign against alcohol by the new General Secretary of the Communist Party of the USSR, Mikhail Gorbachev. Unfortunately, this campaign was short-lived. As both the antialcohol campaign and the wider policy of perestroika faltered, the earlier increase in life expectancy went into reverse. After the USSR broke apart in 1991, life expectancy fell sharply as the successor states were plunged into severe economic crises (Leon et al. 1997). The lowest point was reached in 1994, after which there was an equally rapid 
recovery. Again, however, this positive trend was short-lived (Shkolnikov, McKee, and Leon 2001), as it was reversed in the wake of a major financial crisis that hit Russia in 1998 (Shkolnikov et al. 2004). Remarkably, even though the 15 former Soviet republics had been independent since 1991, these trends were similar across the post-Soviet states until 1998, albeit with peaks and troughs of different magnitudes. After 1998, the three Baltic states, which by then were candidates for entry to the European Union, moved onto a new upward trajectory, which they have-with some minor interruptionssubsequently sustained (Karanikolos et al. in press).

In previous analyses, we have investigated the fluctuations in Russian mortality up to the mid-2000s (Leon et al. 1997; Shkolnikov, McKee, and Leon 2001; Shkolnikov et al. 2004; Shkolnikov, Andreev, and Jdanov 2008). We identified the key role played by the hazardous consumption of alcohol in these fluctuations (McKee, Shkolnikov and Leon 2001; Chenet et al. 1998; Leon, Shkolnikov, and McKee 2009), underpinned by a chaotic and rapid economic and social transition against a backdrop of minimally effective social safety nets (Walberg et al. 1998).

In this paper, we examine events in Russia, the largest of the former Soviet republics, in the years since 2004, the point at which life expectancy once again started to rise. In line with our previous approach, we systematically investigate how deaths from major causes in each age group contributed to this improvement, paying particular attention to the features that differentiate this positive trend from past periods of improvement, when the gains were less enduring. We also compare the current mortality profile in Russia with that of a Western European country (the United Kingdom $^{4}$ ) in order to better understand what additional steps may be required for Russia to converge with the West. Finally, we discuss the factors that may have led to these improvements in life expectancy in Russia, and the possible implications of our findings for future trends.

\section{Methods}

\subsection{Data and techniques}

We used data on mortality in Russia by sex, age, and cause of death since 1965 . For the period 1965 to 1994, the data were extracted from the reconstructed series of mortality by causes of death produced by the Institut National d'Edudes Démographiques (INED,

\footnotetext{
${ }^{4}$ The UK was chosen because it is a large country with life expectancy levels and causes of death that are close to the European averages.
} 
Paris, France) and the Centre for Demography and Human Ecology, Moscow, Russia (Meslé et al. 1996). Compared to the data in the WHO Mortality Database, these data include more detailed causes of death, cover a longer time period, and are adjusted for distortions induced by changes in the classification of causes of death.

For the period 1994 to 2010, similar data were extracted from the original files compiled by Rosstat, the Russian State Statistical Agency. It should be noted that, historically, the Russian statistical system used aggregated diagnostic categories rather than the more detailed International Classification of Diseases (ICD) issued by the World Health Organization. However, in the reconstructed data set, the 175 categories have been mapped onto broad categories within ICD-9. The data series was continued up to 1998. For the period 1999-2010, the data include about 270 causes based on detailed ICD-10 codes. In this paper, we aggregate these categories into broad groupings that are consistent across the time period.

We place the changes in Russia since 1965 within a broader context by comparing them with developments in selected comparator countries, from Eastern Europe (the Czech Republic, Estonia, and Ukraine) and from Western Europe (the UK), with these data extracted from the Human Mortality Database (Human Mortality Database 2012).

We then examined in more detail the change in overall life expectancy in Russia between 2003 and 2010, identifying the contribution of deaths from major causes, and in different age groups using the decomposition method developed by Andreev and colleagues (Andreev 1982; Andreev, Shkolnikov, and Begun 2002). A more detailed analysis of temporal changes in Russia and of the differences between Russia and the UK was undertaken using cause-specific age-standardized death rates. These were (directly) age-standardized using the European Standard Population (Benjamin and Pollard 1980; World Health Organisation Regional Office for Europe, 2012).

\section{Results}

\subsection{Life expectancy at birth in Russia and comparator countries}

Since 1965, Russian trends in life expectancy at birth contrast markedly with those in the UK (Figure 1). While there has been a steady increase in the UK, the overall pattern for most of the period is one of decline for Russian males and stagnation for females. Despite recent improvements, it is particularly striking that life expectancy for men in 2010 was, at 63 years, still below the level achieved in 1965. However, as a result of recent gains, life expectancy for women in 2010 reached 74.8 years; the highest level ever achieved in Russia. These diverging trends have resulted in a widening of the life 
expectancy gap between Russia and the UK from three years for men and 1.5 years for women in 1965, to 15 and seven years, respectively, in 2010.

The other extraordinary feature of the Russian trends shown in Figure 1 is the sharp fluctuation in life expectancy, which became particularly pronounced after 1984, when a series of steep increases and decreases occurred. These can be broken down into a number of phases: an increase in 1985-1987 (during the anti-alcohol campaign), a slow decrease in 1986-1991 (during the weakening of the campaign), a dramatic drop in 1992-1994 (following the collapse of the Soviet Union), an increase in 1995-1998 (a period of adaptation), a decrease in 1999-2003 (following the financial crisis in Russia in August 1998), and, finally, an increase since 2004. This most recent upward trend is of longer duration than any of the other preceding increases or decreases. The rate of improvement varied somewhat across the period. It was low in 2004-5, but greatly accelerated in 2006. A slowdown at the end can be attributed to the summer heat wave in 2010 (Revich and Shaposhnikov 2012).

\section{Figure 1: Trends in life expectancy at birth in Russia and four other countries} since 1965. In years
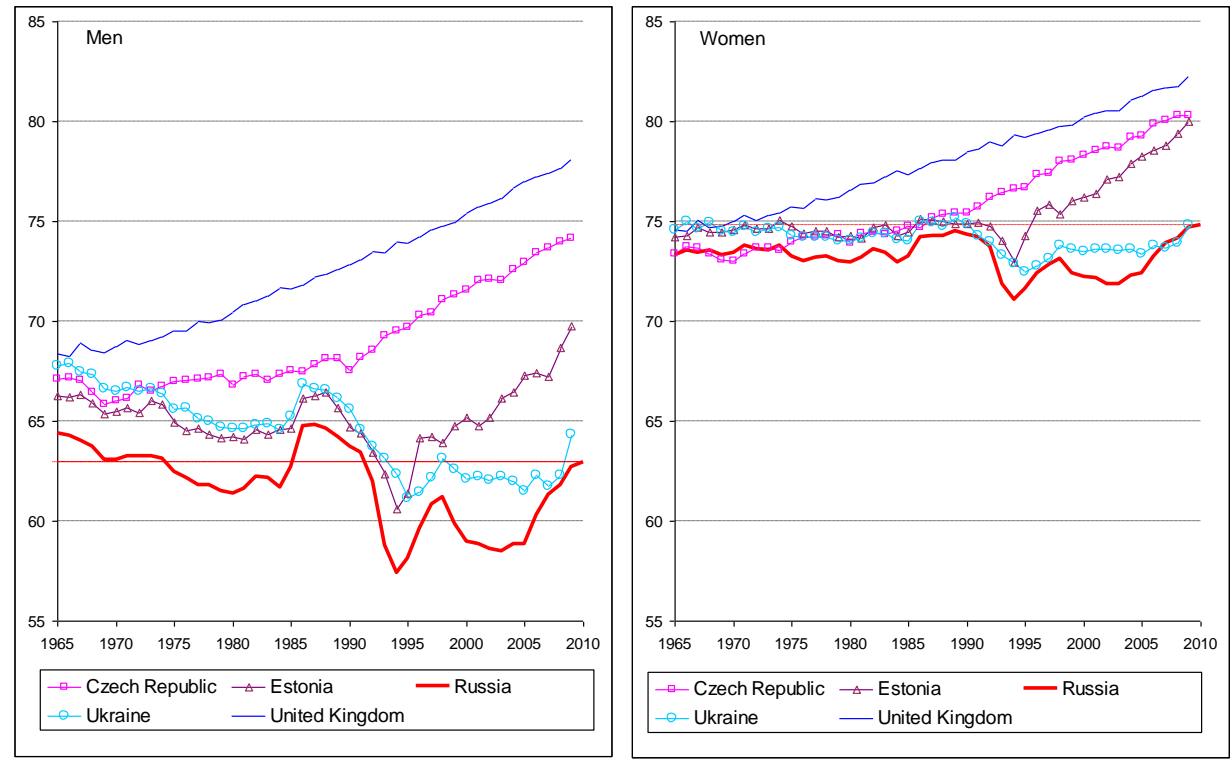
The trends in Ukraine have broadly paralleled those in Russia. Although Estonia initially underwent the same sharp fluctuations in life expectancy, from 1998 onward its trajectory diverged from that of Russia, as the Baltic state experienced steep and consistent increases. Life expectancy in the Czech Republic, which had stagnated in the 1970s and 1980s (Chenet et al. 1996), started to increase almost as soon as communism in Czechoslovakia collapsed in 1989.

\subsection{Age patterns}

Figure 2 shows proportional changes in all-cause mortality at different ages in Russia since 1980. Although the amplitude of variation in each age group is larger for men than women, the pattern is very similar. During the period 1970 to 2003, the wellknown contrast between improvement among children and deterioration or stagnation among adults is apparent. This has long been characteristic of the trends in mortality in Russia (Leon et al. 1997; Shkolnikov, Meslé, and Vallin 1996). Mortality in infancy and childhood had decreased continuously, while mortality in every adult age group has gone up and down with the same tempo. In relative terms, however, these fluctuations have been the most pronounced at the working ages of 15 to 59 .

Since 2000, mortality among children has been decreasing at a faster pace than in the preceding decades. Since 2005, mortality has also declined at every adult age among both men and women, although at ages 50 and above the decline was already underway from 2003. As a consequence, the age-standardized death rates in 2010 were lower than those in 2003 by about $40 \%$ at ages zero to $14,25 \%$ at ages 15 to $59,20 \%$ at ages 60 to 74, and 15\% at ages 75 and older. However, despite this relatively long period of improvement, it was only at ages 75 and above for men and 65 and above for women that mortality in 2010 was lower than at any point in the past. At younger adult ages, mortality in 2010 remained higher than the levels seen in the mid-1980s, when the anti-alcohol campaign was in full swing.

\subsection{Causes of death}

The four panels in Figure 3 show mortality changes for selected causes of death for both sexes. Table A-1, which shows the ICD-10 codes for causes of death in Figure 3; and Figures A-4 and A-3, which present cause-specific trends for men and women, are in the appendix. 
Figure 2: Trends in age-standardized death rates by broad age groups in Russia since 1980. Per 100,000 person-years
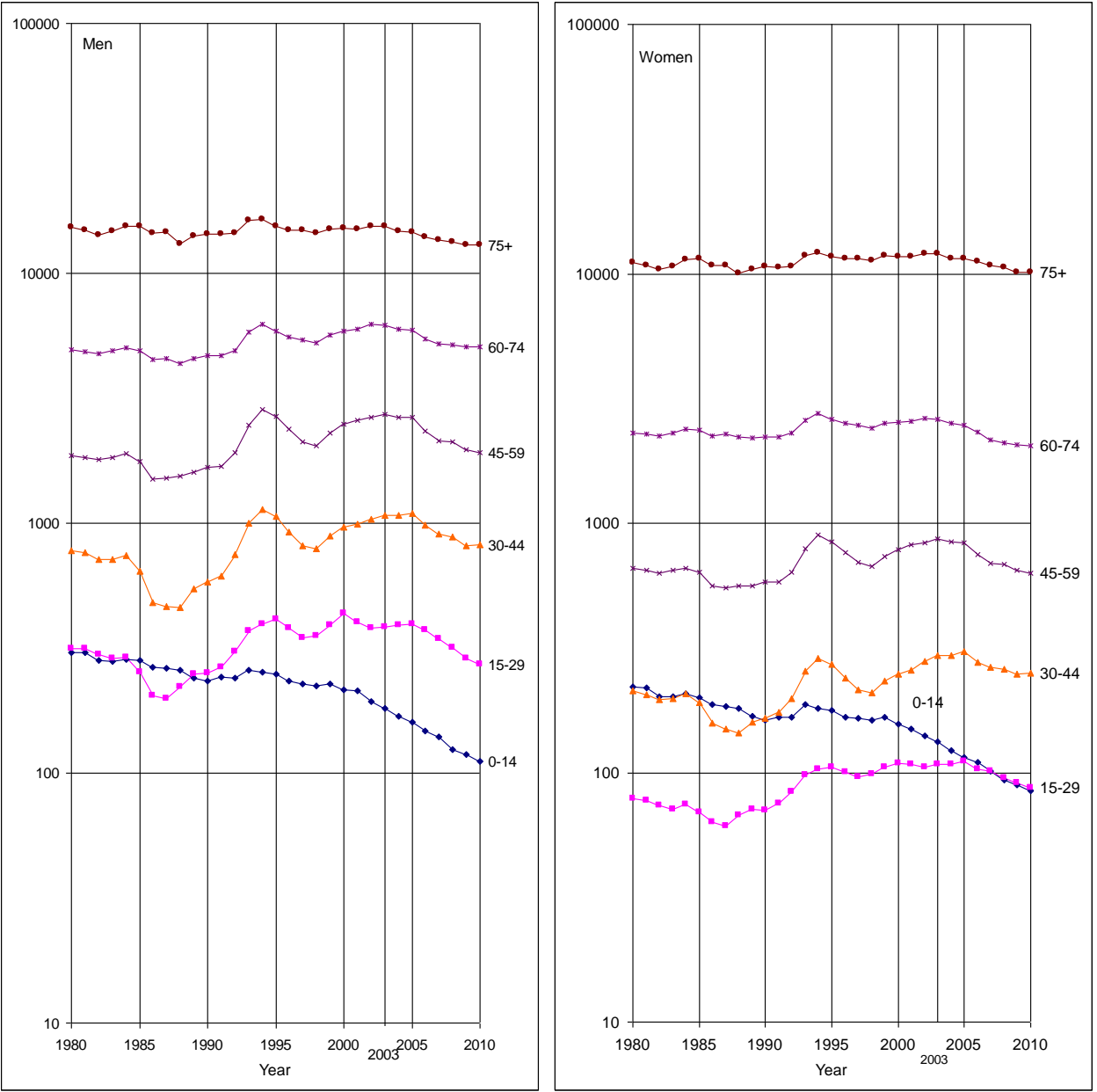

Note: In logarithmic scale. 
The upper two panels of Figure 3 display trends in circulatory diseases and in external and alcohol-related causes. This latter group of causes underwent the largest relative changes. The lower left-hand panel shows mortality trends from various cancers. These are remarkable in that they appear to have had their own dynamic, which was largely independent of the fluctuations seen for most other causes. Most notably, there was no indication of a rise in rates following the collapse of the Soviet Union in the 1990s. The causes of death in the lower-right panel were selected because they are generally regarded as being especially sensitive to medical interventions; thus, fluctuations in the rates at which people die from these causes may reflect changes in the health care system (Nolte and McKee 2004). This is an area in which the USSR increasingly lagged behind Western Europe from the 1960s onwards (Andreev et al. 2003).

It is evident from Figure 3 that the trends for a number of causes of death have been steady, moving either up or down for two decades or more. These include all of the cancers shown. Because of the stability of these trends, none of them is useful in explaining why mortality as a whole declined from 2004 onwards. However, after around 2002-3, all of the other causes of death shown in Figure 3 had either stopped increasing, had plateaued, or had started to decrease. Most notably, mortality from tuberculosis, which had increased consistently since 1990, started to decline in 2006.

The steepest relative declines in the recent period were for external causes. This group of causes, which include those due to violence, is especially strongly associated with alcohol (Pridemore and Chamlin 2006). For deaths from homicide and violence of unknown intent, poisoning by alcohol, and transport accidents, the decline started in 2004. Nevertheless, with the exception of suicide rates, overall mortality from each of these external causes remained higher in 2010 than in the mid-1980s. Given the importance of cerebrovascular disease as a cause of death, the recent declines in this cause are striking. By 2010, mortality rates for cerebrovascular disease had reached the lowest level ever achieved in Russia. However, ischemic heart disease mortality was higher in 2010 than it was in the mid-1980s. 
Figure 3: Trends in age-standardized death rates by selected causes of death in Russia for both sexes since 1970 . Per 100,000 person-years
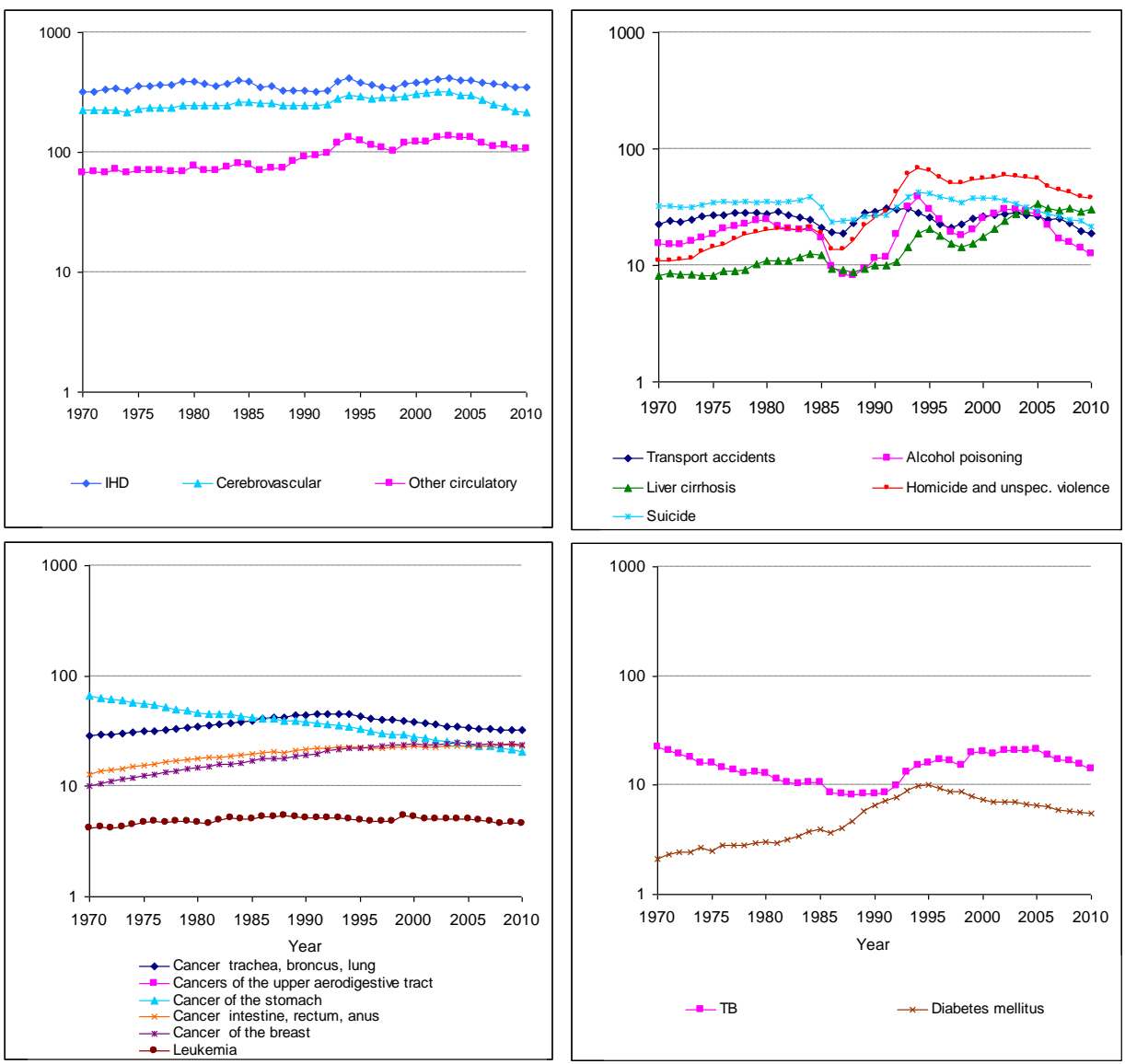

Note 1: In logarithmic scale.

Note 2: ICD codes are given in Table A-1 in the Appendix. 


\subsection{Age- and cause-specific contributions to the increase in life expectancy}

Table 1 shows how these variations in age- and cause-specific-mortality contributed to the increase in Russian life expectancy between 2003 and 2010. An additional table presenting changes in age-standardized death rates between 2003 and 2010 for the same causes of death is in the appendix (Table A-2).

Over this period, male life expectancy at birth increased from 58.50 to 62.95 years, while female life expectancy increased from 71.83 to 74.79 years. Consistent with the trends noted above, reduced mortality at all age groups contributed to the improvements in life expectancy among both males and females. While lower mortality among children ages zero to 14 had a considerable impact on life expectancy, reduced mortality among adults had an even greater effect. Fewer deaths at working ages (45-64 years) had the most significant impact on increased life expectancy among men. Meanwhile, among women, lower mortality at ages 65 and above contributed the most to improvements in life expectancy, although the effect of fewer deaths at ages 45-64 was almost as large.

Reductions in adult mortality from circulatory diseases and external causes were the main drivers of the increase in life expectancy. Neoplasms as a whole had a small positive effect. In the age group 15-44, lower external cause mortality made the biggest contribution to improved life expectancy. In this category, the decrease in the number

of homicides had the greatest impact, although declines in mortality from alcohol poisoning, transport accidents, and suicide (in men) also had significant effects. At older ages, lower mortality from circulatory disease was the primary driver of increased life expectancy. In men and women ages 45-64, reductions in mortality from ischemic heart disease contributed most to the rise in life expectancy; while at ages 65 and above, reductions in mortality from cerebrovascular disease had the biggest impact. Indeed, the decline in cerebrovascular disease mortality was responsible for over half of the total improvement in life expectancy among women ages 65 and above, and for $40 \%$ of the increase among men in this age group. 
Table 1: Decomposition of the life expectancy difference between 2010 and 2003 by ages and selected causes of death for men and women. In years

\begin{tabular}{|c|c|c|c|c|c|c|c|c|c|c|}
\hline \multirow{2}{*}{$\begin{array}{l}\text { Causes of death and corresponding } \\
\text { ICD-10 items }\end{array}$} & \multicolumn{5}{|c|}{ Men } & \multicolumn{5}{|c|}{ Women } \\
\hline & $\begin{array}{c}\text { All } \\
\text { ages }\end{array}$ & $0-14$ & $15-44$ & $45-64$ & $65+$ & $\begin{array}{c}\text { All } \\
\text { ages }\end{array}$ & $0-14$ & $15-44$ & $45-64$ & $65+$ \\
\hline All causes, A00-R99,V01-Y98 & 4.450 & 0.526 & 1.483 & 1.863 & 0.578 & 2.960 & 0.436 & 0.388 & 1.026 & 1.110 \\
\hline Circulatory diseases, 100-199 & 1.384 & -0.004 & 0.209 & 0.783 & 0.395 & 1.549 & -0.005 & 0.056 & 0.601 & 0.897 \\
\hline Ischemic heart disease, I20-I25 & 0.698 & 0.000 & 0.148 & 0.427 & 0.122 & 0.464 & 0.000 & 0.034 & 0.229 & 0.201 \\
\hline Other heart diseases, $126-152$ & 0.100 & -0.007 & 0.024 & 0.085 & -0.002 & 0.042 & -0.006 & 0.005 & 0.060 & -0.017 \\
\hline Cerebrovascular disorders, 160-169 & 0.486 & 0.001 & 0.031 & 0.224 & 0.230 & 0.862 & 0.000 & 0.012 & 0.260 & 0.589 \\
\hline Other circulatory, the rest of 100-199 & 0.100 & 0.001 & 0.006 & 0.048 & 0.046 & 0.181 & 0.001 & 0.005 & 0.052 & 0.123 \\
\hline Neoplasms, C00-D48 & 0.137 & 0.007 & 0.028 & 0.099 & 0.003 & 0.078 & 0.008 & 0.023 & 0.051 & -0.004 \\
\hline $\begin{array}{l}\text { Cancer of trachea, bronchus and lung, } \\
\text { C33-C34 }\end{array}$ & 0.054 & 0.000 & 0.006 & 0.036 & 0.012 & 0.000 & 0.000 & 0.001 & 0.000 & 0.000 \\
\hline $\begin{array}{l}\text { Cancer of the upper aerodigestive } \\
\text { tract, } \mathrm{C} 00-\mathrm{C} 15\end{array}$ & 0.010 & 0.000 & 0.000 & 0.009 & 0.000 & 0.000 & 0.000 & -0.001 & -0.002 & 0.002 \\
\hline Cancer of the stomach, $\mathrm{C} 16$ & 0.052 & 0.000 & 0.005 & 0.032 & 0.015 & 0.042 & 0.000 & 0.006 & 0.020 & 0.016 \\
\hline $\begin{array}{l}\text { Cancer of the intestine, rectum, and } \\
\text { anus, C17-C21 }\end{array}$ & 0.003 & 0.000 & 0.001 & 0.005 & -0.003 & 0.007 & 0.000 & 0.003 & 0.006 & -0.002 \\
\hline Cancer of the female breast, C50 & - & - & - & - & - & 0.021 & 0.000 & 0.008 & 0.020 & -0.007 \\
\hline Cancer of the prostate, $\mathrm{C} 61$ & -0.015 & 0.000 & 0.000 & -0.003 & -0.012 & - & - & - & - & - \\
\hline Other neoplasms, the rest of C00-D48 & 0.033 & 0.007 & 0.016 & 0.019 & -0.009 & 0.009 & 0.009 & 0.006 & 0.007 & -0.013 \\
\hline Selected diseases $\$$ & 0.378 & 0.028 & 0.065 & 0.222 & 0.063 & 0.067 & 0.030 & -0.045 & 0.043 & 0.039 \\
\hline Tuberculosis, A15-A19, B90 & 0.165 & 0.000 & 0.084 & 0.076 & 0.005 & 0.013 & 0.001 & 0.002 & 0.009 & 0.001 \\
\hline $\begin{array}{l}\text { Other infectious, A00-A14, A20-B89, } \\
\text { B91- B99 }\end{array}$ & 0.070 & 0.026 & -0.033 & 0.072 & 0.004 & -0.014 & 0.029 & -0.052 & 0.009 & 0.000 \\
\hline $\begin{array}{l}\text { Alcoholic psychosis and alcoholism, } \\
\text { F10 }\end{array}$ & 0.025 & 0.000 & 0.008 & 0.017 & 0.001 & 0.008 & 0.000 & 0.001 & 0.006 & 0.001 \\
\hline Chronic respiratory disease, J40-J47 & 0.118 & 0.002 & 0.006 & 0.058 & 0.053 & 0.061 & 0.001 & 0.004 & 0.018 & 0.038 \\
\hline $\begin{array}{l}\text { Perinatal and congenital, P00-P96, } \\
\text { Q00-Q99 }\end{array}$ & 0.284 & 0.280 & 0.003 & 0.000 & 0.000 & 0.246 & 0.243 & 0.002 & 0.001 & 0.000 \\
\hline $\begin{array}{l}\text { Other conditions and diseases, the } \\
\text { rest of A00-R99 }\end{array}$ & 0.316 & 0.096 & 0.005 & 0.141 & 0.074 & 0.324 & 0.088 & 0.026 & 0.075 & 0.136 \\
\hline External causes, Y01-Y98 & 1.952 & 0.119 & 1.173 & 0.617 & 0.044 & 0.694 & 0.072 & 0.325 & 0.255 & 0.042 \\
\hline Accidental poisoning by alcohol, X45 & 0.362 & 0.000 & 0.201 & 0.153 & 0.008 & 0.146 & 0.000 & 0.059 & 0.081 & 0.006 \\
\hline Transport accidents, V01-V99 & 0.255 & 0.027 & 0.179 & 0.042 & 0.007 & 0.111 & 0.012 & 0.068 & 0.022 & 0.009 \\
\hline Suicide, $\times 60-X 84$ & 0.311 & 0.005 & 0.201 & 0.092 & 0.012 & 0.052 & 0.000 & 0.025 & 0.019 & 0.008 \\
\hline Homicide, X85-Y09 & 0.380 & 0.012 & 0.272 & 0.089 & 0.007 & 0.151 & 0.007 & 0.092 & 0.042 & 0.009 \\
\hline Violence of unknown intent, Y10-Y34 & 0.086 & 0.002 & 0.026 & 0.059 & -0.001 & 0.031 & 0.001 & 0.011 & 0.022 & -0.002 \\
\hline Other external causes, V01-Y98 & 0.558 & 0.073 & 0.292 & 0.182 & 0.011 & 0.203 & 0.052 & 0.071 & 0.069 & 0.011 \\
\hline
\end{tabular}

Note: ${ }^{\$}$ A15-A19,B90,A00-A14,A20-B89,B91-B99,F10,J40-J47,P00-P96,Q00-Q99. 


\subsection{Russia compared with the UK}

While substantial progress has been made in recent years, mortality in Russia remains very high compared to mortality in other European countries. With a combined life expectancy of 68.9 years, Russia ranked $49^{\text {th }}$ out of 50 countries in Europe in 2010, just ahead of Kazakhstan (World Health Organization Regional Office for Europe 2012). However, in order to understand Russian mortality in an international context, it is helpful to compare it with the mortality of a specific country, rather than of a regional grouping. The country we have chosen for this comparison is the UK. Relative to the rest of Europe, the UK ranks in the middle, with a life expectancy in 2009 of 78.1 years for males and 82.3 years for females.

Overall, the age-standardized total mortality among men is about 2.5 times greater in Russia than it is in the UK, and it is twice as high among women. In fact, at every age mortality in Russia is greater than in the UK, although the size of the gap varies substantially across the age spectrum: in infancy and childhood (0-14 years) mortality is twice as high, at ages 15-44 years it is four times higher, at ages 45-64 it is three times higher, and at ages $65+$ years it is 1.4 times higher.

Table 2 shows the mortality differences between Russia in 2010 and the UK in 2009 by cause and sex. In both absolute and relative terms, the biggest differences were in mortality from circulatory diseases and external causes for males and females, with one notable exception: mortality from tuberculosis. For this latter cause, rates in Russia were 40 times higher among males and 17 times higher among females. In the external cause category, there were very large differences in rates of homicide and alcohol poisoning. The gap in mortality from ischemic heart disease (IHD) was the largest for any cause in absolute terms, although in relative terms the differences for IHD and cerebrovascular disease were similar at between four and five times higher in Russia. Differences in cancer mortality varied by site, with particularly large relative gaps observed for stomach cancer. As can be seen in Table 2, the only categories in which mortality was lower in Russia than in the UK were breast and lung cancers among women. This exceptional advantage was particularly pronounced for lung cancer. 
Table 2: Comparison of age-standardized mortality rates (per 100,000) in Russia (2010) and the United Kingdom (2009) by cause and sex

\begin{tabular}{|c|c|c|c|c|c|c|c|c|}
\hline & \multicolumn{4}{|c|}{ Males } & \multicolumn{4}{|c|}{ Females } \\
\hline & Russia & UK & Diff & Ratio & Russia & UK & Diff & Ratio \\
\hline All causes, A00-R99,V01-Y98 & 1763.1 & 670.7 & 1092.4 & 2.6 & 867.1 & 472.6 & 394.4 & $\overline{1.8}$ \\
\hline Circulatory diseases, 100-199 & 918.6 & 210.9 & 707.7 & 4.4 & 522.2 & 133.7 & 388.6 & 3.9 \\
\hline Ischemic heart disease, 120-125 & 503.2 & 115.6 & 387.6 & 4.4 & 257.5 & 52.2 & 205.2 & 4.9 \\
\hline Other heart diseases, I26-152 & 97.6 & 26.9 & 70.8 & 3.6 & 42.6 & 22.1 & 20.5 & 1.9 \\
\hline Cerebrovascular disorders, 160-169 & 261.5 & 44.1 & 217.4 & 5.9 & 186.4 & 41.7 & 144.7 & 4.5 \\
\hline Other circulatory, the rest of 100-199 & 56.1 & 24.3 & 31.9 & 2.3 & 36.1 & 17.6 & 18.5 & 2.1 \\
\hline Neoplasms, C00-D48 & 265.1 & 209.7 & 55.3 & 1.3 & 133.0 & 151.3 & -18.3 & 0.9 \\
\hline Cancer of trachea, bronchus and lung, C33-С34 & 71.6 & 49.7 & 21.9 & 1.4 & 8.3 & 31.3 & -23.0 & 0.3 \\
\hline Cancer of the upper aerodigestive tract, $\mathrm{C} 00-\mathrm{C} 15$ & 20.4 & 17.4 & 3.1 & 1.2 & 2.9 & 6.3 & -3.3 & 0.5 \\
\hline Cancer of the stomach, $\mathrm{C} 16$ & 33.1 & 7.8 & 25.3 & 4.3 & 13.7 & 3.3 & 10.4 & 4.1 \\
\hline Cancer of the intestine, rectum, and anus, C17-C21 & 30.7 & 22.0 & 8.7 & 1.4 & 19.8 & 13.8 & 6.0 & 1.4 \\
\hline Cancer of the female breast, C50 & - & - & - & - & 23.8 & 25.4 & -1.6 & 0.9 \\
\hline Cancer of the prostate, $\mathrm{C} 61$ & 18.7 & 23.8 & -5.1 & 0.8 & - & - & - & - \\
\hline Other neoplasms, the rest of C00-D48 & 90.5 & 89.0 & 1.5 & 1.0 & 64.5 & 71.3 & -6.8 & 0.9 \\
\hline Selected diseases $\$$ & 81.3 & 44.3 & 37.1 & 1.8 & 19.7 & 31.0 & -11.2 & 0.6 \\
\hline Tuberculosis, A15-A19, B90 & 25.1 & 0.6 & 24.5 & 41.9 & 5.2 & 0.3 & 4.9 & 16.8 \\
\hline Other infectious, A00-A14, A20-B89, B91-B99 & 10.8 & 7.1 & 3.7 & 1.5 & 5.0 & 6.0 & -1.0 & 0.8 \\
\hline Alcoholic psychosis and alcoholism, F10 & 5.5 & 1.8 & 3.7 & 3.1 & 1.5 & 0.7 & 0.8 & 2.1 \\
\hline Chronic respiratory disease, J40-J47 & 40.0 & 34.8 & 5.2 & 1.1 & 8.0 & 24.0 & -16.0 & 0.3 \\
\hline Perinatal and congenital, P00-P96, Q00-Q99 & 11.2 & 8.3 & 2.9 & 1.3 & 9.0 & 7.0 & 2.0 & 1.3 \\
\hline Other conditions and diseases, the rest of A00-R99 & 246.2 & 158.2 & 88.0 & 1.6 & 125.3 & 133.7 & -8.4 & 0.9 \\
\hline External causes, Y01-Y98 & 240.8 & 39.3 & 201.4 & 6.1 & 57.9 & 16.0 & 41.8 & 3.6 \\
\hline Accidental poisoning by alcohol, X45 & 21.2 & 0.6 & 20.6 & 35.4 & 5.4 & 0.3 & 5.1 & 21.0 \\
\hline Transport accidents, V01-V99 & 29.3 & 6.4 & 22.9 & 4.6 & 9.2 & 1.7 & 7.6 & 5.6 \\
\hline Suicide, X60-X84 & 39.4 & 10.5 & 28.9 & 3.7 & 6.6 & 2.8 & 3.8 & 2.4 \\
\hline Homicide, X85-Y09 & 19.9 & 0.4 & 19.5 & 47.5 & 5.7 & 0.2 & 5.5 & 29.9 \\
\hline Violence of unknown intent, Y10-Y34 & 44.6 & 3.2 & 41.4 & 14.0 & 10.1 & 1.3 & 8.7 & 7.6 \\
\hline Other external causes, V01-Y98 & 86.5 & 18.2 & 68.3 & 4.8 & 21.0 & 9.8 & 11.2 & 2.1 \\
\hline
\end{tabular}

Note: ${ }^{\$}$ A15-A19,B90,A00-A14,A20-B89,B91-B99,F10,J40-J47,P00-P96,Q00-Q99. 


\section{Discussion}

This is the first study to examine systematically the increase in life expectancy in Russia that has occurred since 2004. The relatively long and continuous upward trend in life expectancy appears to have broken the pattern observed since the mid-1980s, in which relatively brief periods of improvement were followed by longer periods of deterioration. Recently published data show that life expectancy levels for both men and women have increased by a further 0.8-0.9 years in 2011, reaching 64 years for men and 75.6 years for women (Rosstat 2013).

Our analyses have shown that the recent improvements in life expectancy in Russia have mainly been driven by reductions in mortality from circulatory diseases and external causes. However, the marked improvements in these cause-of-death categories have been reinforced by positive trends in several other causes, most notably in tuberculosis, which increased between the collapse of the Soviet Union to the mid2000s.

\subsection{Limitations}

Before considering possible substantive explanations for these trends, we should note the limitations of our analyses. The main limitation is that the measurements and decompositions presented in this study relate to population-level effects, which cannot be used to establish causal relationships that apply at the level of individuals. These effects do, however, provide the necessary basis for formulating plausible hypotheses regarding the underlying causes of the improvements in life expectancy, and thus allow us to identify promising directions for future research based on more detailed data, which would enable us to better evaluate causal effects.

Beyond this general point, we should note that we used routinely collected mortality data in these analyses. The characteristics and quality of these data were studied in detail in the mid-1990s (Meslé et al. 1996; Shkolnikov, Meslé, and Vallin 1996). These studies found that there was an under-registration of infant and old-age mortality in the 1950s and 1960s, which could have resulted in a slight overstatement of life expectancy in the years before the late 1960s. In addition, the Russian statistical system used a restricted definition of live birth during this period, which led to a $20 \%$ underestimate of the infant mortality rate (Andreev 1995; Kvasha and Kharkova 2011). But since this definition has remained unchanged, the trends in infant deaths were not affected. Problems have also been associated with the registration and coding of causes of death in Russia. These issues have been most acute for the category of circulatory diseases, as some non-specific codes were frequently used when the precise cause of 
death was not known (Shkolnikov et al. 1999). More recently, a number of additional problems have arisen, such as an increase in the number of deaths at unknown ages and from unspecified causes (Shkolnikov, Meslé, and Vallin 1996; Andreev et al. 2008; Gavrilova 2008), and in the number of violent deaths of undetermined intent (Pridemore 2003). For example, rates of homicide and suicide may have been affected by the misclassification of deaths from these two causes as unspecified violent deaths. While all of these problems are relatively minor and cannot affect the estimates of life expectancy and mortality rates by broad groups of causes (Leon et al. 1997; Wassermann and Varnik 1998; Andreev, Scherbov, Willekens 1995), caution is advised when considering more specific and smaller cause-of-death categories, such as diabetes or liver cirrhosis, as there may have been some variation in registration practices.

\subsection{Cause-specific trends and international differences}

There are several important and unique features of recent trends which distinguish them from previous cyclical fluctuations. In 2010, female life expectancy reached an all-time high for Russia. This is attributable in large part to the marked decline in cerebrovascular disease mortality among women, particularly at older ages: among women ages 60 and above (and among men ages 75 and above), all-cause mortality reached a historically low level for Russia, even as the cerebrovascular disease mortality rate fell to its lowest point in four decades. This recent downward trend in cerebrovascular disease mortality brings the level in Russia closer to the levels observed in high-income European countries, where there have seen long-term declines in deaths from this cause (Feigin et al. 2009). Deaths from several other causes in 2010 had also decreased to the lowest levels seen in Russia since 1980, including suicide and stomach cancer. As the rate of stomach cancer had been declining for a very long time, most likely as a result of improvements in conditions during childhood (Leon 2001), this cause is not implicated in the cyclical fluctuations we have observed.

However, for many other causes of death, the 2010 rates were still highersometimes considerably higher - than the lowest points recorded for Russia. For a number of causes, the lowest point was reached at the height of Gorbachev's antialcohol campaign in the mid-1980s. These include deaths caused by acute alcohol poisoning, liver cirrhosis, tuberculosis, and ischemic heart disease. Deaths attributable to diabetes, an eminently avoidable disease, were also higher in 2010 than they were in 1980. Thus, life expectancy in Russia has the potential to increase further simply through a return to mortality levels for certain causes of death that had been achieved at some point in the past. If all of these causes of death (especially causes directly or indirectly related to alcohol) had been at the lowest levels ever recorded for Russia (in 
1987, for most causes), life expectancy in 2010 would have been 69.7 years for men and 78.2 years for women (increases of 6.7 and 3.5 years, respectively). These figures suggest possible benchmarks that are realistically achievable in the short term. It is important to recognize, however, that, although this potential improvement is very substantial, it still would not close the current gap between Russia and the countries with the lowest mortality levels.

One striking observation from our analyses is that the causes of death which have fluctuated the most over time in Russia, and have tended to contribute most to the recent improvements in life expectancy, are generally the causes for which the biggest relative and sometimes absolute differences relative to the UK have been observed. At the other end of the spectrum, the death rates from cancer in Russia were found to have been immune to cyclical mortality fluctuations, to have contributed little to the overall improvement in life expectancy, and to have been more similar to the rates in the UK than for any other cause. Moreover, mortality was shown to have been lower in Russia than in the UK for some cancer sites (e.g., for female lung and breast cancers). However, circulatory disease mortality in Russia was found to have undergone moderate fluctuations over time, to have made a major contribution to recent improvements in life expectancy, and to have been much higher than in the UK. This strongly suggests that the best strategy for bringing life expectancy in Russia closer to European levels lies in tackling mortality from circulatory diseases and external causes.

\subsection{Alcohol}

The most dynamic element of mortality is driven by changeable contemporary conditions. Since the late 1980s, Russian mortality has undergone sharp fluctuations, especially at working ages. Many of these fluctuations have been related to the harmful effects of alcohol consumption (Shkolnikov et al. 2004; Shkolnikov, Andreev, and Jdanov 2008).

The mortality decrease in 2004-2010 was the longest decline since 1965. Apart from the short-term decreases in the 1980s and in the second half of the 1990s, there were two earlier decreases in mortality since 1970: in 1972-1973 and 1981-1982. Both were relatively minor, and were associated with increases in vodka prices in the USSR (Takala 2002). Thus, all of the mortality decreases between 1965 and 2003 were shortlived, and were associated with declines in alcohol consumption. A large fraction of the reduction in mortality between 2003 and 2010 is also attributable to lower alcohol use, including decreases in mortality from alcohol poisoning and other alcohol-related causes, accidents, violence, cardiovascular deaths, and hemorrhagic stroke at working ages. It is important to note that mortality dropped especially sharply after the 
introduction of new federal controls on ethanol production and sales in 2006 (Khalturina and Korotaev 2008; Levintova 2007).

In the group of alcohol-related causes, there currently appears to be a disconnect between liver cirrhosis and other causes. Before 2004, mortality rates from liver cirrhosis and alcohol poisoning had always fluctuated in parallel. However, the substantial decline in acute alcohol poisoning in 2004-2010 was, unusually, accompanied by a persistently high rate of mortality from liver cirrhosis. While we cannot exclude some change in coding practices, this may indicate a reduction in the frequency of the kind of extreme drinking behavior associated with alcohol poisoning, even as the overall level of alcohol consumption remains high, which may be expected to result in chronic damage affecting not only the liver, but also the pancreas, heart, and other organs (Leon et al. 2010).

So far, alcohol control policies in Russia have been characterized by episodic "campaigns," each of which has had some short-term success. The most effective campaign was the one instituted by Gorbachev in 1985. But that initiative, like some earlier small-scale efforts, was based on short-lived, top-down strategies of coercion and control that failed to tackle the underlying causes of hazardous drinking or popular attitudes toward it. The measures implemented in 2006 were broader structural efforts that focused on controlling and limiting supply. Crucially, they required all companies that manufactured ethanol for any purpose to pay a large registration fee to do so. This led to the closure of many smaller companies unable to pay the fee. Those companies that were authorized were then covered by a new monitoring scheme: the United State Automated Information System (USIS). This system allowed for the computerized tracking of ethanol production on the premises where it was actually manufactured. Alongside these measures, industrial ethanol production became subject to excise tax, and a new list of denaturating substances was introduced that made a much larger proportion of non-beverage ethanol unpalatable to drink (Levintova 2007). The introduction of USIS and the excise taxation on all ethanols were particularly important, as they made it much less likely that "hidden" ethanol would be diverted into the production of very cheap vodkas and non-beverage alcohols. This measure was of crucial importance given the compelling evidence that the consumption of ethanol from medical tinctures, eau-de-colognes, after-shaves, and industrial solvents has been a major factor in the high death rates at working ages in Russia (Leon et al. 2007). The net effect of these measures was a reduction in the total production of ethanol in Russia for the first time since 1998 .

Although the measures taken in 2006 are widely believed to have been effective in reducing mortality, there is more to be done. A survey of the availability of nonbeverage alcohols in 17 Russian cities in 2007 showed that these products were still available in many cities (Gil et al. 2009). This indicates the need for stronger 
enforcement. On the other hand, data from the Russian Longitudinal Monitoring Survey (RLMS) (Higher School of Economics 2012) suggest that there have been some favorable changes in drinking patterns that could mark the beginning of a sustained shift. A comparison of Round 9 (2000) and Round 17 (2008) of the RLMS shows that the share of beer in overall consumption of pure ethanol has increased, and the share of vodka has decreased. Among respondents aged 15 to 54, these shares in 2000 were $14.2 \%$ and $56.1 \%(\mathrm{n}=2127)$, respectively; while the shares in 2008 were $31.6 \%$ and $50.9 \%(n=2593)$, respectively. The greatest change has taken place among the young. For example, among respondents aged 20 to 29 , the share of beer in overall consumption increased from $23.2 \%(n=626)$ in 2000 to $51.8 \%(n=622)$ in 2008.

\subsection{Smoking}

In Russia, smoking rates have long been high among men, but have historically been very low among women (Shkolnikov et al. 1999). In contrast, the smoking epidemic in the UK was one of the earliest and most intense in Europe, with smoking among British women becoming common in the middle of the $20^{\text {th }}$ century. Yet smoking-related mortality among men in the UK has been falling for decades, and appears to have peaked for women. However, the situation in Russia is not as promising, as there is no indication that smoking rates have declined among men, and there is good evidence that they are increasing among women (Perlman et al. 2007). Because of the substantial lag effect between smoking and the onset of consequent disease, lung cancer rates among women in Russia are still very low compared to rates among women in the UK. However, this rare health advantage for Russian women, which is also reflected in low rates of smoking-induced circulatory disease, will be lost unless steps are taken to reverse the current upward trend in smoking among women. At the same time, lowering the smoking rates among Russian men is an urgent priority. A trend toward smoking cessation would result in substantial short- to medium-term health gains, given the growing evidence that risks of ischemic heart disease fall rapidly when people stop smoking, reaching levels in line with those of non-smokers within three to five years (Lightwood and Glantz 1997; Capewell and O'Flaherty 2011).

\subsection{Health system performance}

Even as overall mortality was fluctuating between 1985 and 2003, death rates from cardiovascular death at ages 60 and above remained high and relatively stable compared to mortality at younger ages. However, between 2004 and 2010, both all-cause and 
circulatory disease mortality at older ages fell to historically low levels. It is notable that, in this recent period, both the absolute and relative declines were greater for cerebrovascular mortality than for mortality from ischemic heart disease. As with alcohol-related causes, this represented a break with the past, as the fluctuations in mortality from ischemic heart disease had always been much larger than the fluctuations in cerebrovascular mortality. This may be attributable to improved blood pressure control. The management of hypertension has long been poor in Russia, not only because it is under-diagnosed and undertreated, but also because there has been a failure to recognize the need for continuous treatment, rather than for only treating people when they are feeling unwell. Although longitudinal survey data on hypertension management in Russia are scarce, some data are available. Two surveys that posed the same questions in 2001 and 2010 found a slight decrease in the daily use of medication among respondents with a hypertension diagnosis (Roberts et al. 2010; 2012).

Data collected in the framework of the Federal Target Program "Prevention and Treatment of Arterial Hypertension in the Russian Federation" (PTAH, initiated in 2002) (Federal Agency for Health and Social Development 2012) compared blood pressure control in 2003-2004 and in 2009-2010. During that time there was an increase in control of hypertension among women, from $13.7 \%(\mathrm{n}=8233)$ to $19.3 \%(\mathrm{n}=3363)$; but not among men $(10.8 \%, \mathrm{n}=4862$ vs. 10.9\%, $\mathrm{n}=1754)$ (Oganov et al. 2011). Of perhaps greater importance, however, was the significant decrease in the prevalence of highly elevated blood pressure (SBP>170 $\mathrm{mmHg}$ or DBP> $110 \mathrm{mmHg}$ ), from $19 \%$ to $10.1 \%$ among men and from $22.4 \%$ to $10.7 \%$ among women (Shalnova 2012). Unfortunately, in the cited studies the sampling procedures and characteristics of the samples were not described in detail, and thus it is difficult to assess the validity of the findings.

The timing and characteristics of the positive changes in cardiovascular deaths suggest that improvements in the health care system had an impact. The PTAH program may have played a role in the improvement in hypertension control, as it included a package of measures to increase awareness of hypertension and to make the treatment of high blood pressure more effective. However, while the PTAH program may have affected cerebrovascular mortality in particular, it has not been subject to a formal evaluation, and thus there are no data on its coverage or effectiveness. Hence, it is not possible to quantify any positive effects on health the program might have had. The same is true for the other national health initiatives designed to prevent and treat "socially significant diseases" that were launched in 2007. These include programs aimed at diabetes, tuberculosis, HIV infection, cancer, sexually transmitted infections, viral hepatitis, mental disorders, and vaccine-preventable diseases. Of the corresponding causes of death, only the mortality downturn in tuberculosis, which 
began in 2006, approximately coincides with the implementation of the related health program.

The improvement in mortality from treatable cardiovascular causes seen at older ages is echoed in reductions in mortality from some other causes that contributed much less to the overall increase in life expectancy, but which might also be indicative of improvements in health care, and especially of the prevention of premature deaths from causes amenable to health care, such as tuberculosis and diabetes. While deaths from tuberculosis started to decrease in the mid-2000s, a reduction in deaths from diabetes began in the mid-1990s.

Mortality from a number of cancers has also declined. Most of these improvements started gradually in the 1990s. For the most common cancers, such as lung and stomach cancers, these changes were mainly determined by the incidence of these malignancies, and had little to do with medical practices (Shkolnikov et al. 1999; Leon 2001; Zaridze et al. 2002; Zaridze 2012; Davidov and Axel 2011). At the same time, mortality from some less common but more treatable cancers, such as leukemia, has decreased, despite an increase in the incidence of these cancers (Davidov and Axel 2011); again, this is consistent with improvements in medical care.

Although mortality among children under age 15 had been decreasing for decades, this trend accelerated after 2000. The increase has been especially steep for early neonatal mortality, and is therefore mainly attributable to the greater use of advanced technology in perinatal care (Kvasha and Kharkova 2011).

Finally, it is important to note the role played by an ambitious, multi-purpose national priority project, known simply as "Health," which began in 2006 (Popovich et al. 2011). Through the project, the Russian health care system received direct subsidies from the federal budget. According to the WHO Office for Europe, Russia's health expenditure in PPP\$US per capita increased 31\% between 2005 and 2006, and another 33\% between 2006 and 2009 (World Health Organization Regional Office for Europe 2012). The project had four main priorities: the improvement of primary care, including higher salaries for general practitioners in polyclinics (since the beginning of 2006); the strengthening of the emergency care infrastructure; the promotion of high-technology medical care; and the construction by the federal government of new medical centers. Although the project's effects on health have not been objectively evaluated, it is possible that the increased investment has had a positive impact on health outcomes.

According to the Russia's Health Ministry, additional financing of modern medical technologies has resulted in a 2.5 -fold rise in the number of high-technology medical services 5 provided, and in a 2.4 -fold increase in the number of surgeries for ischemic

5 These include surgical interventions and other procedures for treatment and diagnostics which are considered advanced and which are included in the official list by the Ministry of Health of the Russian 
heart disease performed (Minzdravsotsrazvitiya 2012). These interventions might have contributed to the reduction in mortality from ischemic heart disease, and from some other pathologies.

However, despite these initiatives, the health service in Russia is still insufficient to respond adequately to the current health challenges, and many Russians in need of care are not yet receiving it (Balabanova et al. 2012). Thus, recent news that the Russian government intends to substantially reduce health care expenditures in the federal budgets for 2013-2015 is particularly worrying (Ministerstvo finansov Rossii 2012).

\section{Conclusion}

This study represents the first attempt to examine systematically the recent increases in Russian life expectancy. The improvements in the 2000s were mostly driven by decreases in mortality from cardiovascular diseases and external causes among adults. Our finding that the recent reduction in mortality at older ages from circulatory (and especially cerebrovascular) diseases has been greater than the earlier decreases in 19951998 and 1985-1987 is important. To some extent, this development is similar to changes that have taken place in the Czech Republic, Poland, and other Central European countries over the past two decades; as well as to shifts that occurred in the UK and other high-income countries in the 1970s (Meslé 2004; Rychtařiková 2004). Does this mean that Russia is entering a new stage of health transition, known also as "cardiovascular revolution" (Vallin and Meslé 2004)? It is not yet possible to determine whether we are witnessing the beginning of a sustained trend that will allow Russians to join the citizens of other developed countries as they progress toward having longer and healthier lives (Christensen et al. 2009). Further monitoring of mortality trends in Russia and detailed comparisons with earlier developments in other countries remain a priority for future research if we are to understand the ongoing changes in Russia.

The measures to improve health through primary and secondary prevention of disease that have already been taken should be continued and reinforced. The profile of excess mortality in Russia relative to Western Europe suggests that the priorities in Russia should be discouraging alcohol consumption and tobacco use, and the provision of more effective and universally available health care.

Federation (Ministry of Health of the Russian Federation, 2012). Such procedures are financed at a higher level (compared to "normal" medical activities) from special funds within the framework of the national priority project "Health." 


\section{Acknowledgements}

During the study, VMS and EMA were with the Max Planck Institute for Demographic Research in Rostock (Germany), which is funded by the Max Planck Gesellschaft (Germany); and the New Economic School in Moscow (Russia), which is funded by the "Dynasty" Foundation (Russia). DAL and MM were employed by the London School of Hygiene \& Tropical Medicine in the European Centre on Health of Societies in Transition. 


\section{References}

Andreev, E., Scherbov, S., and Willekens, F. (1995). Sources of information on the population of Russia. Groningen: University of Groningen Press.

Andreev, E., Pridemore, W.A., Shkolnikov, V.M., and Antonova, O.I. (2008). An investigation of the growing number of deaths of unidentified people in Russia. European Journal of Public Health 18(3): 252-257. doi:10.1093/eurpub/ ckm124.

Andreev, E.M. (1982). Metod komponent v analize prodoljitelnosty zjizni. [The method of components in the analysis of length of life]. Vestnik Statistiki 9: 42-47.

Andreev, E.M. (1995). Mladencheskaya smertnost' v Rossii [Infant mortality in Russia]. Voprosi Statistiki [Statistical Issues] 5: 66-71.

Andreev, E.M., Nolte, E., Shkolnikov, V.M., Varavikova, E., and McKee, M. (2003). The evolving pattern of avoidable mortality in Russia. International Journal of Epidemiology 32(3): 437-446. doi:10.1093/ije/dyg085.

Andreev, E.M., Shkolnikov, V.M., and Begun, A.Z. (2002). Algorithm for decomposition of differences between aggregate demographic measures and its application to life expectancies, healthy life expectancies, parity-progression ratios and total fertility rates. Demographic Research 7(14): 499-522. doi:10.4054/DemRes.2002.7.14.

Balabanova, D., Roberts, B., Richardson, E., Haerpfer, C., and McKee, M. (2012). Health care reform in the former soviet union: Beyond the transition. Health Services Research 47(2): 840-864. doi:10.1111/j.1475-6773.2011.01323.x.

Benjamin, B. and Pollard, J.H. (1980). The analysis of mortality and other actuarial statistics. London: Heineman.

Capewell, S. and O'Flaherty, M. (2011). Rapid mortality falls after risk-factor changes in populations. The Lancet 378(9793): 752-753. doi:10.1016/S01406736(10)62302-1.

Chenet, L., McKee, M., Fulop, N., Bojan, F., Brand, H., Hort, A., and Kalbarczyk, P. (1996). Changing life expectancy in central Europe: Is there a single reason? Journal of Public Health 18(3): 329-336. doi:10.1093/oxfordjournals. pubmed.a024514. 
Chenet, L., McKee, M., Leon, D., Shkolnikov, V., and Vassin, S. (1998). Alcohol and cardiovascular mortality in Moscow; new evidence of a causal association. Journal of Epidemiology and Community Health 52(12): 772-774. doi:10.1136/jech.52.12.772.

Christensen, K., Doblhammer, G., Rau, R., and Vaupel, J.W. (2009). Ageing populations: The challenges ahead. The Lancet 374(9696): 1196-1208. doi:10.1016/S0140-6736(09)61460-4.

Davidov, M. and Axel, E.M. (2011). Zabolevaemost' ${ }^{\star}$ zlokachestvennimi $^{2}$ novoobrazovaniyami [Morbidity by malignant neoplasms]. Bulletin of Research Institute, RAMS 22(3 (Appendix 1)): 54-92.

Federal Agency for Health and Social Development (2012). The Federal Target Program "Preventive maintenance and treatment of arterial hypertension in the Russian Federation". Moscow: Government of the Russian Federation. http://fcp.economy.gov.ru/cgi-bin/cis/fcp.cgi/Fcp/ViewFcp/View/2006/80.

Feigin, V.L., Lawes, C.M., Bennett, D.A., Barker-Collo, S.L., and Parag, V. (2009). Worldwide stroke incidence and early case fatality reported in 56 populationbased studies: A systematic review. The Lancet Neurology 8(4): 355-369. doi:10.1016/S1474-4422(09)70025-0.

Gavrilova, N.S., Semyonova, V.G., Dubrovina, E., Evdokushkina, G.N., Ivanova, A.E., and Gavrilov, L.A. (2008). Russian mortality crisis and the quality of vital statistics. Population Research and Policy Review 27(5): 551-574. doi:10.1007/s11113-008-9085-6.

Gil, A., Polikina, O., Koroleva, N., McKee, M., Tomkins, S., and Leon, D.A. (2009). Availability and characteristics of nonbeverage alcohols sold in 17 Russian cities in 2007. Alcoholism: Clinical and Experimental Research 33(1): 79-85. doi:10.1111/j.1530-0277.2008.00813.x.

Higher School of Economics (2012). Russian Longitudinal Monitoring Survey. Moscow: Higher School of Economics. http://www.cpc.unc.edu/projects/rlmshse.

Human Mortality Database (2012). University of California at Berkeley (USA) and Max Planck Institute for Demographic Research (Germany). http://www.mortality.org.

Karanikolos, M., Leon, D.A., Smith, P.C., and McKee, M. (in press). Minding the gap: Changes in life expectancy in the Baltic States compared to Finland. Journal of Epidemiology and Community Health. 
Khalturina, D.A. and Korotaev, A.V. (2008) Vvedeniye. Alkogolnaya katasrofa: kak ostanovit vimiraniye Rossii. [Introduction. How to stop dying of Russia]. In: Khalturina, D.A. and Korotayev, A.V. (eds.). Alkogolnaya katastrofa Vozmozhnosti gosudarstevennoy politiki v preodolenii alkogolnoy smertnosti $v$ Rossii [Alcohol catastrophe and options for state policy for surmounting the alcohol mortality in Russia]. Moscow: Lenand: 5-58.

Kvasha, E.A. and Kharkova, T.L. (2011) Smertnost' mladentsev v Rossii: Uspekhi i nereshennye problemy. [Infant mortality in Russia: Successes and unresolved issues]. Demoscope Weekly 461-462: 1-17.

Leon, D.A. (2001). Common threads: Underlying components of inequalities in mortality between and within countries. In: Leon, D.A. and Walt, G. (eds.). Poverty, Inequality, and Health. Oxford: Oxford University Press: 58-87.

Leon, D.A., Chenet, L., Shkolnikov, V.M., Zakharov, S., Shapiro, J., Rakhmanova, G., Vassin, S., and McKee, M. (1997). Huge variation in Russian mortality rates 1984-94: Artefact, alcohol, or what? The Lancet 350(9075): 383-388. doi:10.1016/S0140-6736(97)03360-6.

Leon, D.A., Saburova, L., Tomkins, S., Andreev, E., Kiryanov, N., McKee, M., and Shkolnikov, V.M. (2007). Hazardous alcohol drinking and premature mortality in Russia: A population based case-control study. The Lancet 369(9578): 20012009. doi:10.1016/S0140-6736(07)60941-6.

Leon, D.A., Shkolnikov, V.M., and McKee, M. (2009). Alcohol and Russian mortality: A continuing crisis. Addiction 104(10): 1630-1636. doi:10.1111/j.13600443.2009.02655.x.

Leon, D.A., Shkolnikov, V.M., McKee, M., Kiryanov, N., and Andreev, E. (2010). Alcohol increases circulatory disease mortality in Russia: Acute and chronic effects or misattribution of cause? International Journal of Epidemiology 39(5): 1279-1290. doi:10.1093/ije/dyq102.

Levintova, M. (2007). Russian alcohol policy in the making. Alcohol and Alcoholism 42(5): 500-505. doi:10.1093/alcalc/agm040.

Lightwood, J.M. and Glantz, S.A. (1997 ). Short-term economic and health benefits of smoking cessation: Myocardial infarction and stroke. Circulation 96(4): 10891096. doi:10.1161/01.CIR.96.4.1089.

McKee, M., Shkolnikov, V., and Leon, D.A. (2001). Alcohol is implicated in the fluctuations in cardiovascular disease in Russia since the 1980s. Annals of Epidemiology 11(1): 1-6. doi:10.1016/S1047-2797(00)00080-6. 
McMichael, A.J., McKee, M., Shkolnikov, V., and Valkonen T. (2004). Mortality trends and setbacks: Global convergence or divergence? The Lancet 363(9415): 1155-1159. doi:10.1016/S0140-6736(04)15902-3.

Meslé, F. (2004). Mortality in Central and Eastern Europe: Long-term trends and recent upturns. Demographic Research, Special Collection 2(3): 45-70. doi:10.4054/DemRes.2004.S2.3.

Meslé, F., Shkolnikov, V.M., Hertrich, V., and Vallin, J. (1996). Tendences recentes de la mortalite par cause en Russie 1965-1994. Serie: Donées Statistiques 2. Paris: INED.

Ministerstvo finansov Rossii (2012). Osnovniye napravleniya budzhetnoi politiki na 2013 god i na planoviy period 2014 i 2015 godov. Materialy k zasedaniyu Pravitelstva Rossiyskoy Federatsii 6 iyulya 2012 goda. [Principal dimensions of the budget policies for 2013 and for the planning period 2014 and 2015. Materials for the Session of the Government of the Russian Federation on the $6^{\text {th }}$ of July 2012][electronic resource]. http://www.consultant.ru/law/hotdocs/ 20071.html.

Minzdravsotsrazvitiya Rossii (2012). Meditsina visokikh technologiy stala dostupnee. [High-tech medicine has become more affordable]. Form number 14. "Information on the activities of the hospital," 2006-2011. Moscow: Ministry of Health and Social Development.

Minzdrav Rossii (2012). Proekt prikaza Minzdrava Rossii ot 22 oktyabrya 2012 g. Ob utverzhdenii perechnya vidov vysokotechnologichnoi pomoschi. [Project of the decree of the Ministry of Health of Russia of the $22^{\text {nd }}$ of October 2012. On the approval of the list of high-tech medical services]. http://rosminzdrav.ru/ docs/mzsr/projects/1784.

Nolte, E. and McKee, M. (2004). Does health care save lives? Avoidable mortality revisited. London: The Nuffield Trust.

Oganov, R.G., Timofeeva, T.N., Koltunov, I.E., Konstantinov, V.V., Balanova, Z.A., Kapustina, A.V., Leltschuk, I.N., Shalnova, S.A., and Deev, A.D. (2011). Arterial hypertension epidemiology in Russia. The results of 2003-2010 federal monitoring. Kardiovaskularnaya Terapiya i Profilaktika 10(1): 8-12.

Perlman, F., Bobak, M., Gilmore, A., and McKee, M. (2007). Trends in the prevalence of smoking in Russia during the transition to a market economy. Tobacco Control 16(5): 299-305. doi:10.1136/tc.2006.019455. 
Popovich, L., Potapchik, E., Shishkin, S., Richardson, E., Vacroux, A., and Mathivet, B. (2011). Russian Federation health system review. Health Systems in Transition 13(7): 1-190.

Pridemore, W.A. (2003). Measuring homicide in Russia: A comparison of estimates from the crime and vital statistics reporting systems. Social Science \& Medicine 57(8): 1343-1354. doi:10.1016/S0277-9536(02)00509-9.

Pridemore, W.A. and Chamlin, M.B. (2006). A time series analysis of the effects of heavy drinking on homicide and suicide rates in Russia, 1956-2002. Addiction 101(12): 1719-1729. doi:10.1111/j.1360-0443.2006.01631.x.

Revich, B.A. and Shaposhnikov, D.A. (2012). Climate change, heat waves, and cold spells as risk factors for increased mortality in some regions of Russia. Studies on Russian Economic Development 23(2): 195-207. doi:10.1134/S10757007 12020116.

Roberts, B., Stickley, A., Balabanova, D., Haerpfer, C., and McKee, M. (2012). The persistence of irregular treatment of hypertension in the former Soviet Union. Journal of Epidemiology and Community Health 66(11): 1078-1082. doi:10.1136/jech-2011-200645.

Roberts, B., Stickley, A., Balabanova, D., and McKee, M. (2010). Irregular treatment of hypertension in the former Soviet Union. Journal of Epidemiology and Community Health 66(6): 482-488. doi:10.1136/jech.2010.111377.

Rosstat (2013). The Russian Federal Service for Statistics. Demography. http://www.gks.ru/wps/wcm/connect/rosstat_main/rosstat/ru/statistics/population /demography/\#.

Rychtařiková, J. (2004). The case of the Czech Republic. Determinants of the recent favourable turnover in mortality. Demographic Research, Special Collection 2(5): 105-138. doi:10.4054/DemRes.2004.S2.5.

Shalnova, S.A. (2012). Control of arterial hypertension - a surety of reduction of cardiovascular morbidity and mortality. Presented at the VII All-Russia Congress "Arterial Hypertension from A.L.Myasnikov to our days", Moscow, 5 March 2012.

Shkolnikov, V., McKee, M., Leon, D., and Chenet, L. (1999). Why is the death rate from lung cancer falling in the Russian Federation? European Journal of Epidemiology 15(3): 203-206. doi:10.1023/A:1007546800982. 
Shkolnikov, V., McKee, M., and Leon, D.A. (2001). Changes in life expectancy in Russia in the mid-1990s. The Lancet 357(9260): 917-921. doi:10.1016/S01406736(00)04212-4.

Shkolnikov, V.M., Andreev, E.M., and Jdanov, D.A. (2008). Smetrnost trudosposobnogo naseleniya, alkogol i prodolzhitelnost zhizni $\mathrm{v}$ Rossii. [Mortality of working-age population, alcohol and length of life in Russia. In: Khalturina, D.A. and Korotayev A.V. (eds.). Alkogolnaya katastrofa Vozmozhnosti gosudarstevennoy politiki v preodolenii alkogolnoy smertnosti $v$ Rossii [Alcohol catastrophe and options for state policy for surmounting the alcohol mortality in Russia]. Moscow: Lenand: 85-104.

Shkolnikov, V.M., Andreev, E.M., Leon, D.A., McKee, M., Meslé, F., and Vallin, J. (2004). Mortality reversal in Russia: The story so far. Hygiea Internationalis 4(1): 29-80. doi:10.3384/hygiea.1403-8668.044129.

Shkolnikov, V.M., McKee, M., Vallin, J., Aksel, E., Leon, D., Chenet, L., and Meslé, F. (1999). Cancer mortality in Russia and Ukraine: Validity, competing risks and cohort effects. International Journal of Epidemiology 28(1): 19-29. doi:10.1093/ ije/28.1.19.

Shkolnikov, V.M., Meslé, F., and Vallin, J. (1996). Health crisis in Russia I. Recent trends in life expectancy and causes of death. Population: An English Selection 8: $123-154$.

Takala, I.R. (2002). Veselie Rusi: Istorija alkogol'noj problemy v Rossii [A fun of the Rus': History of the alcohol problem in Russia]. Sankt-Peterburg: Zurnal Neva, Nauécnoe izd. ed.

Vallin, J. and Meslé, F. (2004). Convergences and divergences in mortality. A new approach to health transition. Demographic Research, Special collection "Determinants of Diverging Trends in Mortality" 2(2): 11-44. doi:10.4054/DemRes.2004.S2.2.

Walberg, P., McKee, M., Shkolnikov, V., Chenet, L., and Leon, D.A. (1998). Economic change, crime, and mortality crisis in Russia: Regional analysis. British Medical Journal 317(7154): 312-318. doi:10.1136/bmj.317.7154.312.

Wasserman, D. and Varnik, A. (1998). Reliability of statistics on violent death and suicide in the former USSR, 1970-1990. Acta Psychiatrica Scandinavica 98(Suppl. 394): 34-41. doi:10.1111/j.1600-0447.1998.tb10763.x. 
World Health Organisation, Regional Office for Europe (2012). Health for All Database. Copenhagen: World Health Organisation Regional Office for Europe. http://www.euro.who.int/en/what-we-do/data-and-evidence/databases/europeanhealth-for-all-database-hfa-db2.

Zaridze, D.G. (2012). Onkologicheskaya mifologiya I realnost' [Cancer Mythology and Reality]. Независимая газета [Independent Newspaper]. http://www.ng.ru/ health/2012-06-26/8_oncology.html.

Zaridze, D.G., Karpov, R.S., Kiseleva, S., Konobeevskaia, I.N., Men' T.X., Shain, A.A., and Shikhman, S.M. (2002). Kureniye - osnovnaya prichina visokoi smertnosti rossiyan [Smoking - the main cause of high mortality of Russians]. Вестник РАMH [Journal of Medical Sciences] 9: 40-45. 


\section{Appendix}

Table A-1: Causes of death in Figures 3, A-3, A-4 and the corresponding ICD-10 items

\begin{tabular}{|c|c|}
\hline Causes of death in Figure 3 & ICD-10 codes \\
\hline \multicolumn{2}{|l|}{ The upper-left panel } \\
\hline IHD & $120-125$ \\
\hline Cerebrovascular & $160-169$ \\
\hline Other circulatory & The rest of 100-199 \\
\hline All cardiovascular, ages 0-64 & $100-199$ \\
\hline \multicolumn{2}{|l|}{ The upper-right panel } \\
\hline Transport accidents & V01-V99 \\
\hline Alcohol poisoning & X45 \\
\hline Cirrhosis of liver & $\mathrm{K} 70, \mathrm{~K} 74$ \\
\hline Suicide & X60-X84 \\
\hline Homicide & X85-V09 \\
\hline Violence undetermined intent & Y10-Y34 \\
\hline Homicide and unspecified violence & X85-Y34 \\
\hline \multicolumn{2}{|l|}{ The lower-left panel } \\
\hline Cancer trachea, bronchus, lung & C33, C34 \\
\hline Cancers of the upper aero-digestive tract & $\mathrm{C} 00-\mathrm{C} 15$ \\
\hline Cancer of the stomach & C16 \\
\hline Cancer of the intestine, rectum, anus & $\mathrm{C} 17-\mathrm{C} 21$ \\
\hline Cancer of the breast & C50 \\
\hline Leukemia & C91-C95 \\
\hline \multicolumn{2}{|l|}{ The lower-right panel } \\
\hline Rheumatic cardiopathies & $105-109$ \\
\hline TB & A15-A19,B90 \\
\hline Other infectious diseases & The rest of $\mathrm{A} 00-\mathrm{B} 99$ \\
\hline Diabetes mellitus & E10-E14 \\
\hline Chronic respiratory diseases & J40-J47 \\
\hline
\end{tabular}


Figure A-2: Trends in age-standardized death rates by selected causes of death in Russia for males since 1970. Per 100,000 person-years
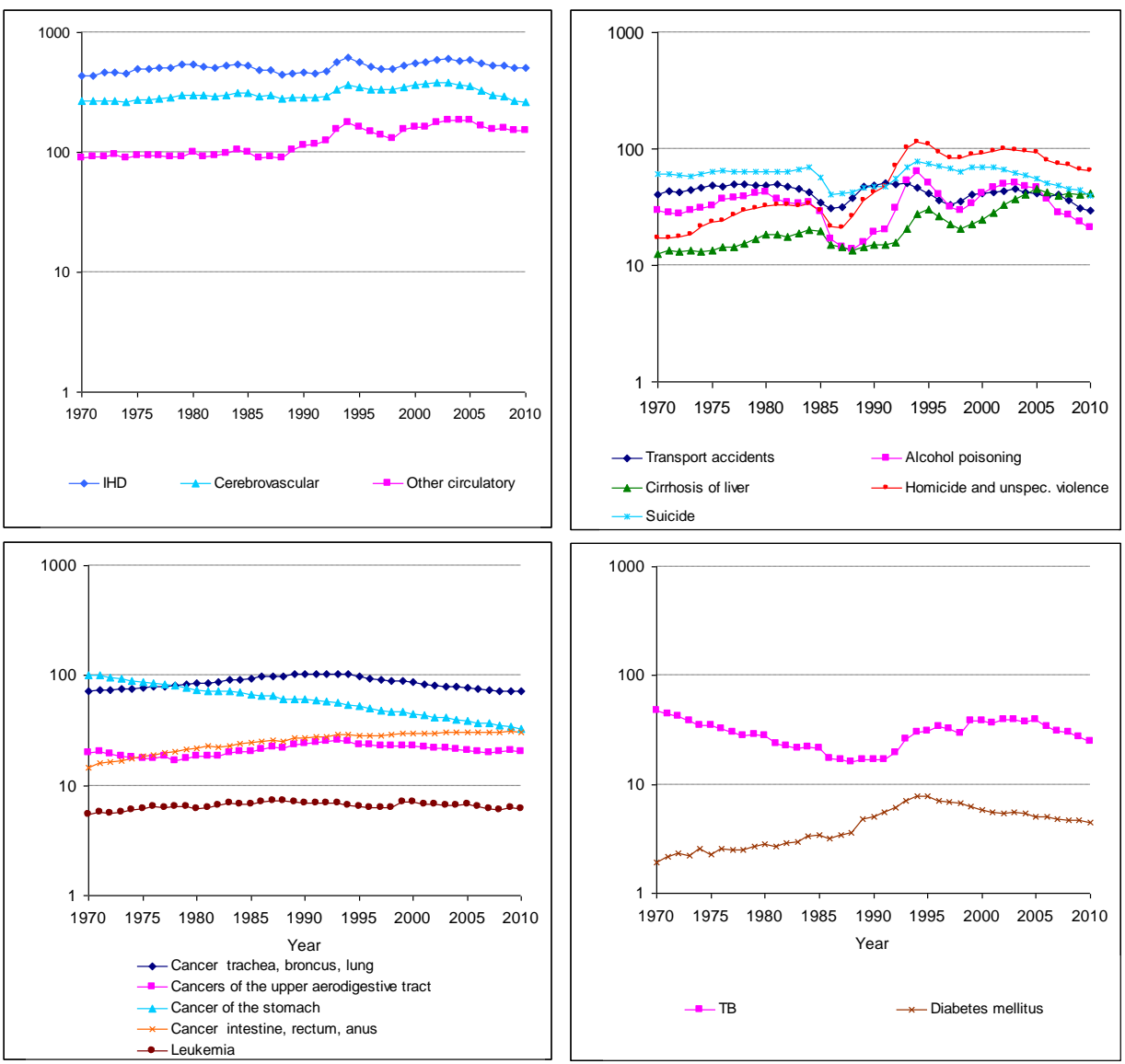

Note 1: In logarithmic scale.

Note 2: ICD codes are given in Table A-1. 
Figure A-3: Trends in age-standardized death rates by selected causes of death in Russia for females since 1970 . Per 100,000 person-years
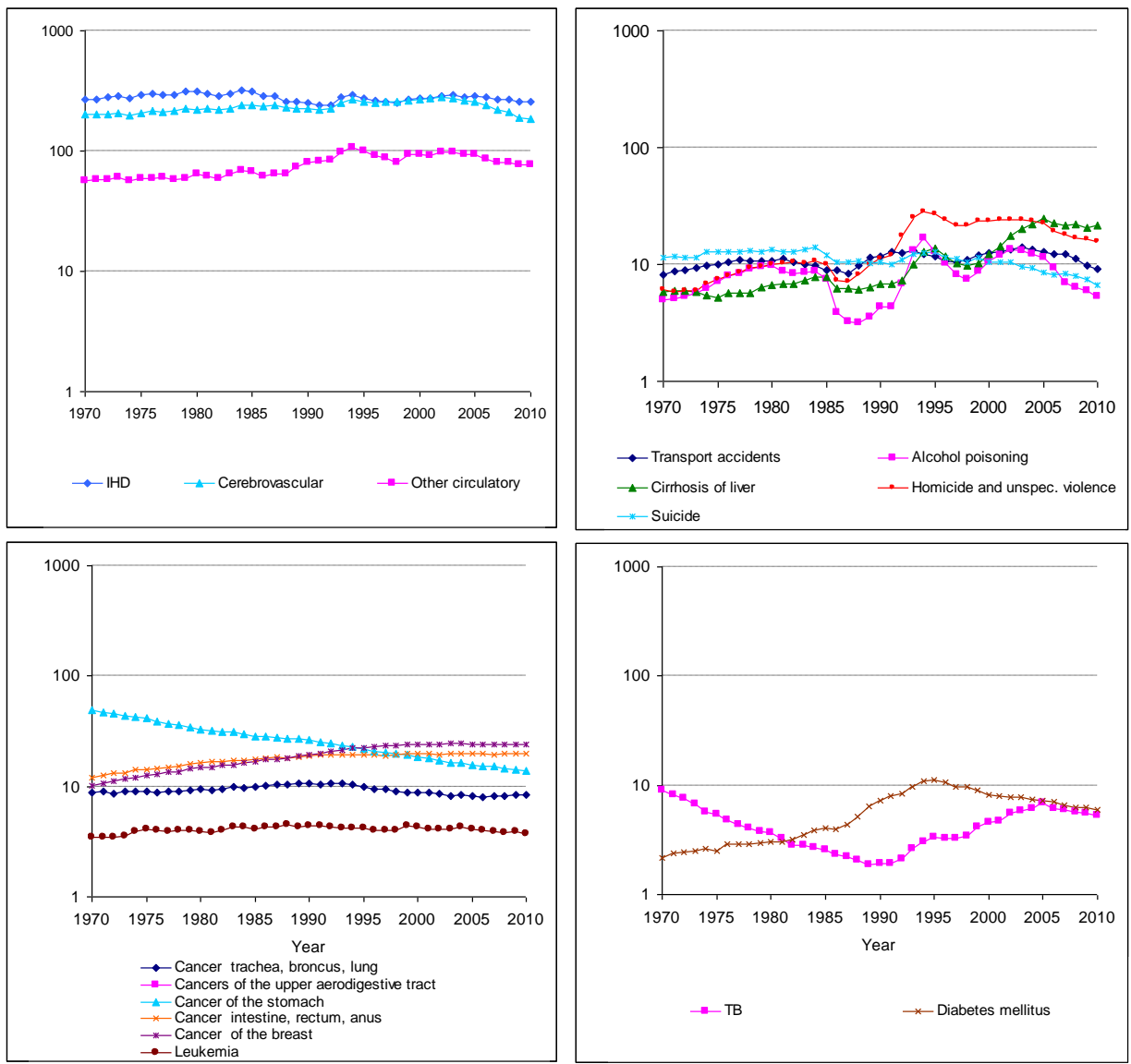

Note 1: In logarithmic scale.

Note 2: ICD codes are given in Table A-1. 
Table A-4: Comparison of age-standardized death rates (per 100,000) between 2003 and 2010 by cause and sex in Russia

\begin{tabular}{|c|c|c|c|c|c|c|c|c|}
\hline & \multicolumn{4}{|c|}{ Males } & \multicolumn{4}{|c|}{ Females } \\
\hline & 2003 & 2010 & Diff & Ratio & 2003 & 2010 & Diff & Ratio \\
\hline All causes, A00-R99,V01-Y98 & 2253.4 & 1763.1 & 490.3 & 1.3 & 1081.5 & 867.1 & 214.4 & 1.2 \\
\hline Circulatory diseases, 100-199 & 1172.9 & 918.6 & 254.3 & 1.3 & 672.4 & 522.2 & 150.1 & 1.3 \\
\hline Ischemic heart disease, 120-125 & 605.1 & 503.2 & 101.9 & 1.2 & 293.7 & 257.5 & 36.3 & 1.1 \\
\hline Other heart diseases, 126-152 & 106.5 & 97.6 & 8.8 & 1.1 & 43.2 & 42.6 & 0.6 & 1.0 \\
\hline Cerebrovascular disorders, $160-169$ & 378.7 & 261.5 & 117.2 & 1.4 & 276.9 & 186.4 & 90.5 & 1.5 \\
\hline Other circulatory, the rest of 100-199 & 82.3 & 56.1 & 26.2 & 1.5 & 59.4 & 36.1 & 23.3 & 1.6 \\
\hline Neoplasms, C00-D48 & 278.5 & 265.1 & 13.4 & 1.1 & 135.3 & 133.0 & 2.3 & 1.0 \\
\hline Cancer of trachea, bronchus and lung, C33-C34 & 79.4 & 71.6 & 7.8 & 1.1 & 8.2 & 8.3 & -0.2 & 1.0 \\
\hline Cancers of the upper aerodigestive tract, $\mathrm{C} 00-\mathrm{C} 15$ & 21.7 & 20.4 & 1.3 & 1.1 & 3.1 & 2.9 & 0.1 & 1.0 \\
\hline Cancer of the stomach, C16 & 41.4 & 33.1 & 8.3 & 1.3 & 16.6 & 13.7 & 2.9 & 1.2 \\
\hline Cancer of the intestine, rectum, and anus, C17-C21 & 30.4 & 30.7 & -0.3 & 1.0 & 19.8 & 19.8 & 0.0 & 1.0 \\
\hline Cancer of the female breast, $\mathrm{C} 50$ & - & - & - & - & 24.5 & 23.8 & 0.7 & 1.0 \\
\hline Cancer of the prostate, $\mathrm{C} 61$ & 14.5 & 18.7 & -4.2 & 0.8 & - & - & - & - \\
\hline Other neoplasms, the rest of C00-D48 & 91.0 & 90.5 & 0.5 & 1.0 & 63.3 & 64.5 & -1.2 & 1.0 \\
\hline Selected diseases ${ }^{\$}$ & 116.2 & 81.3 & 34.9 & 1.4 & 25.3 & 19.7 & 5.6 & 1.3 \\
\hline Tuberculosis, A15-A19, B90 & 39.1 & 25.1 & 14.0 & 1.6 & 5.9 & 5.2 & 0.6 & 1.1 \\
\hline Other infectious, A00-A14, A20-B89, B91- B99 & 5.3 & 10.8 & -5.5 & 0.5 & 3.5 & 5.0 & -1.5 & 0.7 \\
\hline Alcoholic psychosis and alcoholism, F10 & 7.9 & 5.5 & 2.5 & 1.5 & 1.9 & 1.5 & 0.5 & 1.3 \\
\hline Chronic respiratory disease, J40-J47 & 63.8 & 40.0 & 23.8 & 1.6 & 14.1 & 8.0 & 6.0 & 1.7 \\
\hline Perinatal and congenital, P00-P96, Q00-Q99 & 18.7 & 11.2 & 7.6 & 1.7 & 14.4 & 9.0 & 5.4 & 1.6 \\
\hline Other conditions and diseases, the rest of A00-R99 & 286.4 & 246.2 & 40.2 & 1.2 & 143.6 & 125.3 & 18.2 & 1.1 \\
\hline External causes, Y01-Y98 & 380.7 & 240.8 & 139.9 & 1.6 & 90.5 & 57.9 & 32.7 & 1.6 \\
\hline Accidental poisoning by alcohol, $\mathrm{X} 45$ & 50.7 & 21.2 & 29.5 & 2.4 & 13.1 & 5.4 & 7.8 & 2.5 \\
\hline Transport accidents, V01-V99 & 45.0 & 29.3 & 15.7 & 1.5 & 14.0 & 9.2 & 4.8 & 1.5 \\
\hline Suicide, $\mathrm{X60-X84}$ & 62.7 & 39.4 & 23.4 & 1.6 & 9.6 & 6.6 & 3.0 & 1.5 \\
\hline Homicide, X85-Y09 & 44.6 & 19.9 & 24.7 & 2.2 & 12.5 & 5.7 & 6.9 & 2.2 \\
\hline Violence of unknown intent, $\mathrm{Y} 10-\mathrm{Y} 34$ & 52.1 & 44.6 & 7.6 & 1.2 & 11.5 & 10.1 & 1.5 & 1.1 \\
\hline Other external causes, V01-Y98 & 125.5 & 86.5 & 39.0 & 1.5 & 29.7 & 21.0 & 8.7 & 1.4 \\
\hline
\end{tabular}

Note: ${ }^{\$}$ A15-A19,B90,A00-A14,A20-B89,B91-B99,F10,J40-J47,P00-P96,Q00-Q99. 
Shkolnikov et al.: Components and possible determinants of decrease in Russian mortality in 2004-2010 